\title{
Description of the free-swimming juvenile stages of Lernaeocera branchialis (Pennellidae), using traditional light and confocal microscopy methods
}

\author{
A. J. Brooker*, J. E. Bron, A. P. Shinn \\ Institute of Aquaculture, University of Stirling, Stirling FK9 4LA, UK
}

\begin{abstract}
The last detailed morphological descriptions of the juvenile stages of the parasitic copepod Lernaeocera branchialis (L., 1767) were written more than $70 \mathrm{yr}$ ago, since which time both taxonomic nomenclature and available imaging technologies have changed substantially. In this paper a re-description of the free-swimming juvenile stages of $L$. branchialis is presented using a combination of traditional light microscopy and modern laser scanning confocal microscopy (LSCM) techniques. Detailed descriptions are provided of the nauplius I, nauplius II and copepodid stages and comparisons are made with the findings for other siphonostomatoids. Nauplius II is previously undescribed and several structures are described at the terminal tip which have not been found in other pennellids. With renewed interest in $L$. branchialis as a result of expanding gadoid aquaculture in North Atlantic countries, this re-description provides important information on its life history that may be useful for further research into this potentially devastating pathogen.
\end{abstract}

KEY WORDS: Parasitic Crustacea $\cdot$ Confocal $\cdot$ Morphology Resale or republication not permitted without written consent of the publisher

\section{INTRODUCTION}

Lernaeocera branchialis (L., 1767) is a pennellid copepod that has a 2-host life cycle and whose final mature stage parasitises a range of gadoids. Once attached to the final host, females exhibit gigantism as a result of massive expansion in the length and girth of the genital complex and the production of a substantial holdfast (Kabata 1979). Most segmental boundaries are lost during this transformation (Sproston 1942) and there is considerable morphological plasticity in adult females of the genus Lernaeocera (Blainville, 1822) due to resistance encountered as the parasite grows through the host tissues. As a consequence there are many different 'biological forms', which have resulted in the misidentification of some species, generating much debate amongst taxonomists (Brooker et al. 2007).
The taxonomic descriptions of Lernaeocera branchialis span almost a century, from the earliest account by Scott (1901) to more recent descriptions provided by Boxshall (1992). The most recent, detailed description of the juvenile stages, however, was provided by Sproston (1942). Most other descriptions have concentrated on either the premetamorphosed or metamorphosed adult female (Schuurmans-Stekhoven 1936, Capart 1948, Kabata 1979). Other species within the genus Lernaeocera were proposed and described (Wilson 1917, Schuurmans-Stekhoven 1936, Kabata 1957, 1958), but these were later dismissed as different biological forms of L. branchialis (Kabata 1961, 1979, Van Damme \& Ollevier 1995). The mouthparts of $L$. branchialis have been studied extensively, but due to disagreement between Scott (1901), Sproston (1942) and Capart (1948), Kabata (1962) attempted a re-examination of the mouthparts, which were 
finally described more completely by Kabata (1979) and by Boxshall (1990).

Taxonomic nomenclature and systematics have developed and changed considerably since Sproston's original description of the juvenile stages and technological advancements in microscopy have made it possible to study specimens in greater detail. Therefore a re-examination of the free-swimming juvenile stages is presented in this study, using a combination of both light microscopy and laser scanning confocal microscopy (LSCM).

\section{MATERIALS AND METHODS}

Whiting Merlangius merlangus (L.) and, to a lesser degree, cod Gadus morhua (L.) infected with Lernaeocera branchialis were sampled from the catches of commercial demersal trawlers working within the River Forth Estuary at Kincardine, Scotland ( $56^{\circ} 02^{\prime} 53^{\prime \prime} \mathrm{N}$, $3^{\circ} 40^{\prime} 59^{\prime \prime} \mathrm{W}$ ). To culture the juvenile stages of $L$. branchialis, egg strings were dissected from gravid female parasites collected from infected whiting and cod. These were then maintained under aeration in $500 \mathrm{ml}$ beakers kept in a WTB Binder Labortechnik precision environmental chamber at $10^{\circ} \mathrm{C}$. Once the eggs began to hatch they were placed in a beaker of fresh aerated seawater (35 ppt) and after a period of time ( $20 \mathrm{~min}$ to $24 \mathrm{~h}$ ) the egg strings were transferred to another beaker of fresh seawater, leaving behind a 'batch' of nauplii. These batches were then used for experiments as either nauplii or copepodids, depending on how long they were maintained (nauplius I $<20$ min, nauplius II $<32 \mathrm{~h}$, copepodid $>32 \mathrm{~h}$ ).

Lernaeocera branchialis specimens for traditional light microscopy were prepared by clearing individuals in $85 \%$ lactic acid (Sigma L1250) for 30 min, which also softened the connective tissues, and then by dissecting them on a cavity slide using fine mounted needles under a dissecting microscope. Individual appendages from each specimen were mounted in $100 \%$ glycerol (Sigma G7757) and then sealed with clear nail varnish once a coverslip had been placed over them. Both whole and dissected specimens were viewed on an Olympus BX51 compound microscope and digital micrographs were taken using a Zeiss AxioCam MRc camera and MRGrab 1.0.0.4 software (Carl Zeiss Vision, 2001), these being used as the basis for initial drawings. For several light micrographs in this paper, a series of images at different focal depths were combined using Helicon Focus image stacking software (Helicon Soft) to improve the clarity of the image.
Specimens for LSCM were prepared by fixing them in $2.5 \%$ glutaraldehyde ( $>1$ wk to enhance autofluorescence), and then rinsing them in distilled water when required. They were then stained with either Blankophor $(150 \mu \mathrm{l}$ in a watch glass filled with $5 \mathrm{ml}$ distilled water for $2 \mathrm{~h}$ ) (ICN Biomedicals) or Gomori's trichrome (Gomori 1950) overnight before rinsing again with distilled water. Individual specimens were then placed into a $35 \mathrm{~mm}$ glass base dish (Iwaki) and covered with distilled water before being imaged on a Leica TCS SP2 AOBS laser scanning confocal microscope coupled to an inverted Leica DMIRE2 microscope equipped with a HC PL APO $20 \times$ objective. The samples were imaged using 2 laser excitation lines (UV diode laser $405 \mathrm{~nm}$ and argon laser $488 \mathrm{~nm}$ ) with fluorescence emission collected at 411 to $483 \mathrm{~nm}$ and 498 to $587 \mathrm{~nm}$. Using the Leica Confocal Software v6.21 8-bit TIFF images were obtained, with an image size of $1024 \times 1024$, $2048 \times 2048$ or $2048 \times 1024$ pixels, depending on the size of the specimen. Image stacks comprising between 138 and 280 images were scanned with an automatically optimised section thickness to maximise resolution (range 0.5 to $1.34 \mu \mathrm{m}$ ). Specimen outlines were generated from LSCM composite images in Adobe Photoshop CS3 v.10.0 (Adobe Systems, 2007) using the trace contour filter (Brooker et al. 2012, this issue).

\section{RESULTS}

No visible morphological differences were seen between Lernaeocera branchialis larval stages originating from whiting and those originating from cod. The following descriptions relate to larvae originating from whiting. Measurements, where provided, were taken from larvae hatching from several egg strings, using LSCM images ( $\mathrm{n}=5$ to 13 ).

\section{Nauplius I}

The body shape of the nauplius I is ovoid and the nauplius carries 3 pairs of appendages (Fig. 1). The mean length of the nauplius I was $452.35 \pm 31.85 \mu \mathrm{m}$ and the mean width was $214.36 \pm 16.21 \mu \mathrm{m}(\mathrm{n}=10)$. Between the antennules and anterio-dorsal to the spherical eye lenses, a small papilla is found along the median line (5 in Fig. 1). This may be the precursor to the rostral gland which contributes towards the frontal filament in later stages. Along the lateral margins of the posterior aspect are 2 slim setae or 


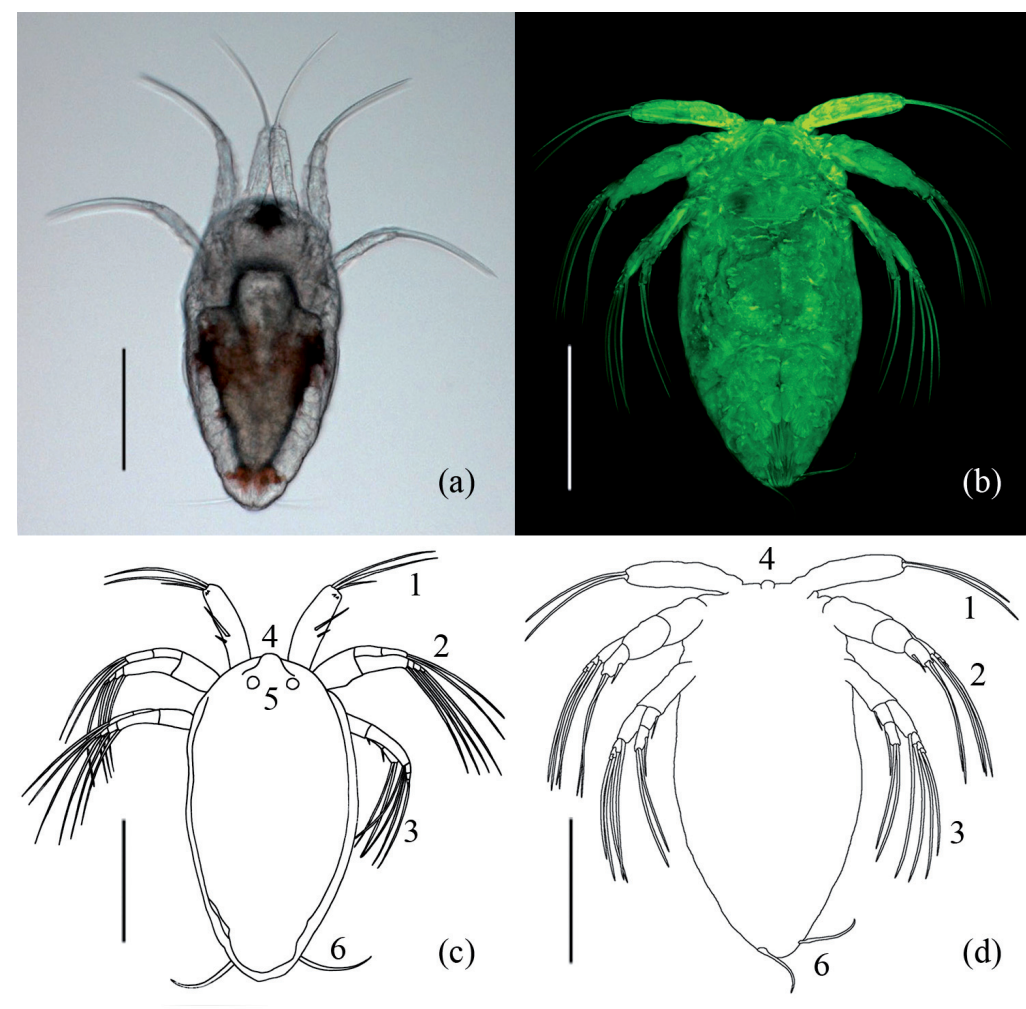

Fig. 1. Lernaeocera branchialis (L., 1767). Nauplius I. (a) Light micrograph (dorsal aspect), (b) confocal composite image (ventral aspect), (c) line drawing (dorsal aspect), (d) line drawing (ventral aspect). Scale bars: $100 \mu \mathrm{m}$. Labels: 1, antennule; 2, antenna; 3, mandible; 4, eye lenses; 5, median papilla; 6 , balancers

'balancers' which are held at right angles to the body (6 in Fig. 1). Distinct regions of dark red pigmentation consisting of globular deposits occur around the middle region of the body and the posterior, while an area of black pigmentation is seen between the eye lenses (Fig. 1a).

The sub-cylindrical, uniramous antennules arise ventrally from the anterior aspect and are unjointed (1 in Fig. 1). Two unarmed setules are found dorsally, midway along the endopod (1 in Fig. 2), the distal setule ( 2 in Fig. 2) being longer than the proximal setule ( 3 in Fig. 2). At the terminal tip, 2 long plumose setae (4 in Fig. 2) and 1 unarmed setule (5 in Fig. 2) are found. Two spines occur dorsally in the subterminal region (6 in Fig. 2).

The biramous antennae (2 in Fig. 1) arise ventrally along the anterior lateral margins and consist of a sympod ( 7 in Fig. 2 d) with a 4 -jointed exopodite ( 8 in Fig. 2d) and a 2-jointed endopodite (9 in Fig. 2d); the exopodite being more slender than the endopodite. The proximal ramus of the exopodite is longer than the other 3 rami combined and the terminal tip of each ramus bears a long plumose seta (10 in Fig. 2d).
On the inner margin of the endopodite, at the base of the distal ramus, is an unarmed setule (12 in Fig. 2d) and at the terminal tip are 2 long plumose setae (10 in Fig. 2d).

The mandibles ( 3 in Fig. 1) arise ventrally and posterior to the antennae. The segmentation is identical to the antennae, although they are slimmer. As in the antenna, each ramus of the exopodite ( 8 in Fig. 2f) bears a long plumose seta at its tip (10 in Fig. 2f). At the base of both rami of the endopodite (9 in Fig. 2f), an unarmed setule (11 and 12 in Fig. 2f) is found on the inner margin, and 2 long plumose setae (10 in Fig. 2) are found at the terminal tip of the distal ramus.

\section{Nauplius II}

The body shape of the nauplius II is similar to that of the nauplius I except for the fact that the anterior aspect is more flattened and the anterior tapers to a finer point (Fig. 3). The mean length of the nauplius II was $489.51 \pm$ $25.67 \mu \mathrm{m}$ and the mean width was $213.95 \pm 9.33 \mu \mathrm{m}(\mathrm{n}=8)$. The body pigmentation in the nauplius II occurs around the middle and posterior regions of the body although it is more extensive and darker than in the nauplius I. The appendages are almost identical to those of the nauplius I, except for the spines found on the antennules (Fig. 4a,b). The antennule (1 in Fig. 3) carries an unarmed setule (2 in Fig. 4) around midway along the endopod ( 1 in Fig. 4 ) and a thick spine (3 in Fig. 4) sub-terminal to the tip. The 2 short spines (6 in Fig. 4) and 1 unarmed setule (5 in Fig. 4) between the 2 plumose setae ( 4 in Fig. 4 ) are identical to those found in the nauplius I. Along the lateral margins of the terminal region of the body, 2 balancers are found (13 in Fig. 4), as in the nauplius I, but also 4 small protrusions (14 in Fig. 4), which may be the developing setae of the caudal rami found in later stages (15 in Fig. 4). At the terminal tip, a paired structure is found, which is likely to be part of the developing caudal rami (G. A. Boxshall pers. comm.). Through the cuticle of the nauplius II, the developing setae of the copepodid swimming legs are visible in older specimens and these extend into the caudal rami. 

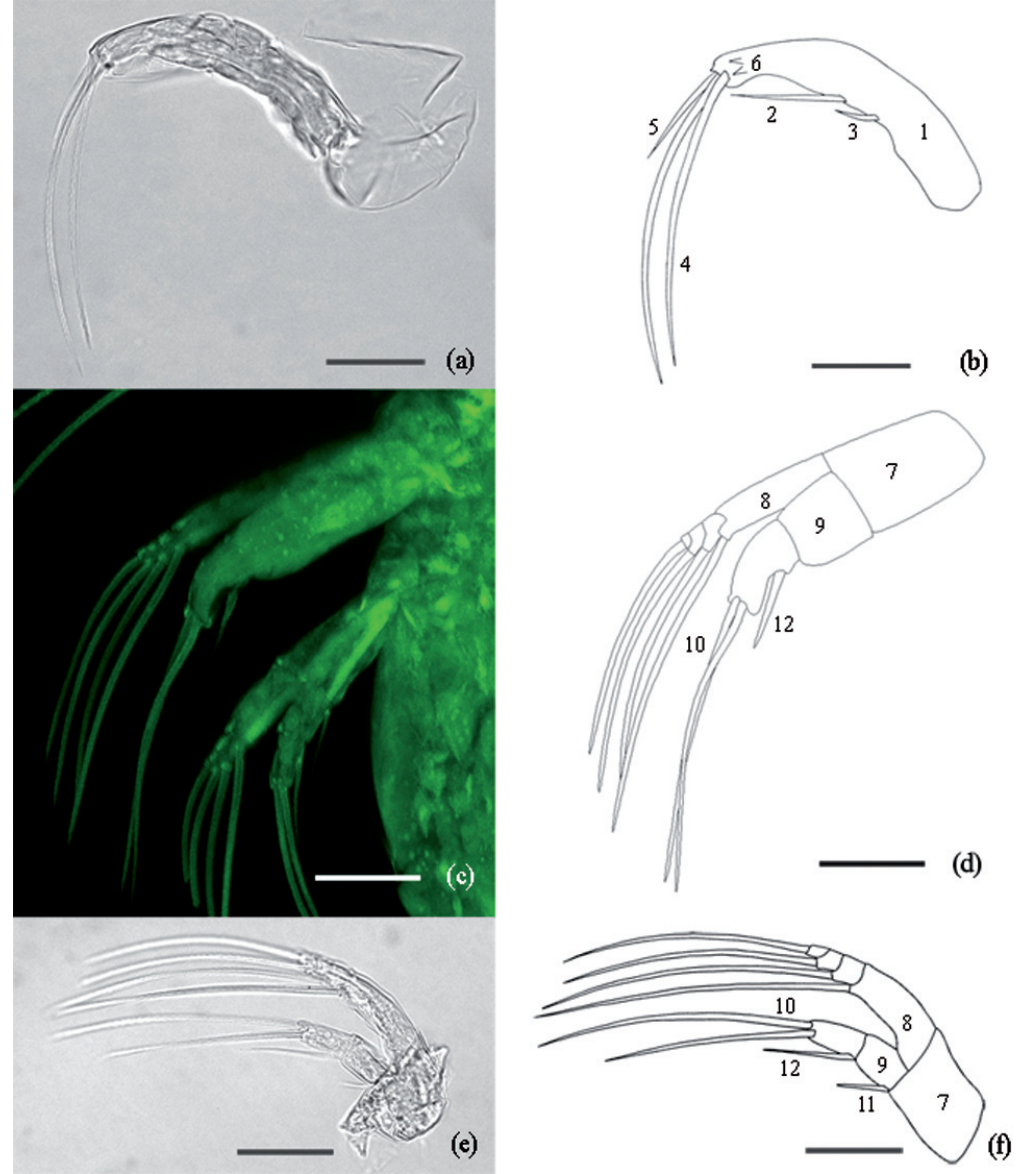

Fig. 2. Lernaeocera branchialis (L., 1767). Nauplius I. (a) Antennule, light micrograph (phase contrast), (b) antennule, line drawing, (c) antenna, confocal composite image, (d) antenna, line drawing, (e) mandible, light micrograph (phase contrast), (f) mandible, line drawing. Scale bars: $50 \mu \mathrm{m}$. Labels: 1, endopod; 2, distal median setule (unarmed); 3, proximal median setule (unarmed); 4, plumose setae (hairs omitted); 5 , terminal setule (unarmed); 6, sub-terminal spines; 7, sympod; 8, exopodite; 9, endopodite; 10, plumose setae (hairs omitted); 11, proximal setule (unarmed); 12, distal setule (unarmed)

\section{Copepodid}

The cephalothorax of the copepodid comprises about 5 eighths of the body length and shows a strong ventral infolding along the lateral margins (Fig. 5). The mean length of the copepodid was $627.95 \pm 45.42 \mu \mathrm{m}$ and the mean width was $242.89 \pm$ $21.22 \mu \mathrm{m}(\mathrm{n}=13)$. The body displays black pigmentation with the darkest pigmentation around the eye lenses (Fig. 5a). Pigmentation in the thoracic segments is dark red to black.

Copepodid specimens were observed both freeswimming and attached to a gill tip by a frontal filament. In specimens attached to a gill tip, the frontal filament consists of a conical strand arising from the ventral face of the rostral gland and embeds into the host's tissue before becoming bifurcated (15 in Fig. 5). Each branch terminates in a large, spherical swelling. Apart from the frontal filament, the free-swimming and attached copepodids are identical, indicating that the moult takes place after the copepodid is secured to the gill tip of the host and that there is only 1 copepodid stage.

The antennules arise ventrally from the anterior of the copepodid (1 in Fig. 5) and are indistinctly 4-segmented (Fig. 6), with a constriction near the terminal end (1 in Fig. 6) indicating the segmental boundary of a fifth segment. The second and third rami each bear 1 seta ( 2 and 3 in Fig. 6). The terminal ramus bears 1 seta proximal to the constriction (4 in Fig. 6) and 13 setae (5 in Fig. 6) plus 1 long, stout aesthetasc (6 in Fig. 6 ) at the terminal tip. All the setae are unarmed.

The antennae are found ventrally and posterior to the antennules (2 in Fig. 5). They consist of 2 broad, heavily chitinised, short segments ( 7 and 8 in Fig. 6) and the terminal ramus is chelated, with a stout hook fitting into a shallow groove at the tip (10 in Fig. 6). These are used to anchor the copepodid to the gill tip of the intermediate host and prevent it from being dislodged by the strong currents in the gill chamber. On the distal border of the terminal segment a small blunt process is found (9 in Fig. 6).

The buccal tube is posterior to the antennae and is located on the ventromedial line (3 in Fig. 5). The labrum (11 in Fig. 6) and labium (12 in Fig. 6) have not yet fused at this stage and each contributes an equal portion to the buccal tube (13 in Fig. 6). On the anterior outer edge of the buccal tube is a thick plaque (14 in Fig. 6 ), which acts as a spring, allowing the buccal tube to form a close seal for feeding (Kabata 1962). Inside the buccal tube, 2 buccal stylets project downwards (15 in Fig. 6). The uniramous mandibles arise laterally to the buccal tube (4 in Fig. 5) and are long, slender appendages (Fig. $7 a, b)$. The proximal section (1 in Fig. 7) is cylindrical and broader than the distal section (2 in Fig. 7), which is flat with a dentiferous margin to the terminal tip, armed with 8 teeth. In this stage they are not yet inserted into the buccal tube. Found laterally to the mandibles, the maxillules ( 5 in 

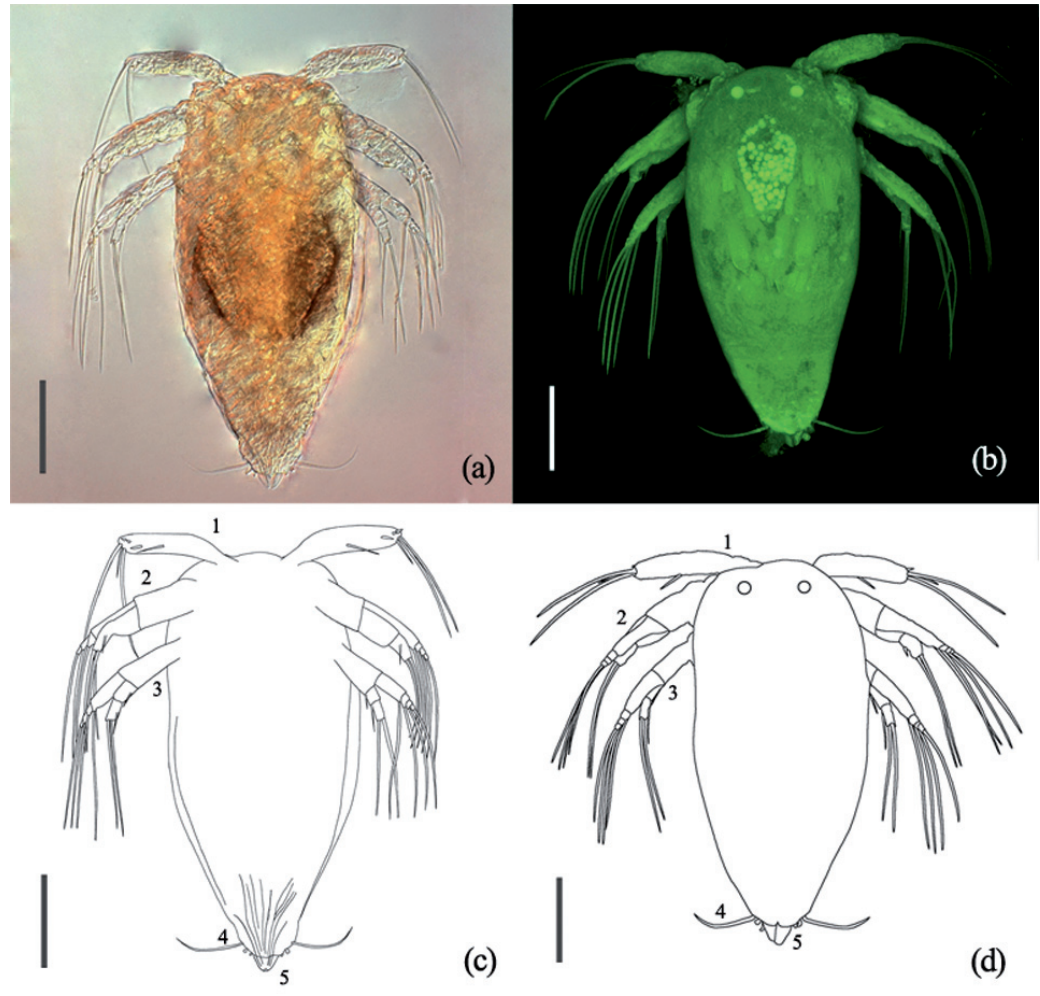

(c)

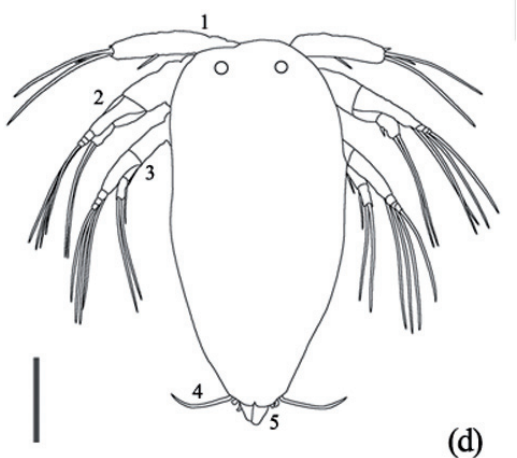

Fig. 3. Lernaeocera branchialis (L., 1767). Nauplius II. (a) Light micrograph (phase contrast) combined image stack (ventral aspect), (b) confocal composite image (dorsal aspect), (c) line drawing (ventral aspect) (d) line drawing (dorsal aspect). Scale bars: $100 \mu \mathrm{m}$. Labels: 1, antennule; 2, antenna; 3, mandible; 4 , balancers; 5 , posterior process

Fig. 5) are bilobed, with the inner lobe (3 in Fig. 7) bearing 2 setae ( 5 in Fig. 7 ) and the outer lobe (4 in Fig. 7) bearing a single seta (6 in Fig. 7). The maxillae are found ventrally and posterior to the mouth tube $(6$ in Fig. 5), and consist of 2 segments: a broad basal ramus (7 in Fig. 7) and a narrower terminal ramus (8 in Fig. 7), which is hooked and blade-like at the terminal tip.

Two pairs of biramous swimming legs are present, the first (8 in Fig. 5) attached to the first thoracic somite, which is fused to the cephalothorax, and the second (9 in Fig. 5) attached to the second thoracic somite (10 in Fig. 5). Both pairs of legs are connected by an intercoxal sclerite, which ensures each pair of legs beats simultaneously. The first swimming leg consists of a broad, flat protopod (1 and 2 in Fig. 8b), bearing an exopodite ( 3 in Fig. $8 b$ ) and an endopodite (4 in Fig. 8b), each consisting of a single ramus. A short plumose setule is found at the lateral margin of the basis (5 in Fig. 8b). The exopodite arises from the basis ( 2 in Fig. 8b) close to the lateral margin of the joint between the coxa (1 in Fig. 8b) and basis. The distal margin of the exopodite bears 4 long, (d)

plumose setae (9 in Fig. 8b) plus a papilliform outgrowth (8 in Fig. $8 b$ ) and a short, blunt spine ( 7 in Fig. 8b) on the dorso-lateral margin. A single spine (6 in Fig. 8b) is found half way along the anterior edge. The outermost seta narrows around one quarter of the length from its base and carries a fringe of short hairs on one edge (10 in Fig. 8b). The endopodite bears 7 long, plumose setae (9 in Fig. 8b) along its distal margin. The second swimming leg is very similar to the first, except for the fact that the endopodite (4 in Fig. $8 d$ ) bears only 6 setae (9 in Fig. 8d).

Five thoracic somites are present, although the first cannot be distinguished as it is fused to the cephalothorax (Huys \& Boxshall 1991). The second somite (10 in Fig. 5) is also fused to the cephalothorax but is clearly visible as a separate segment. The third somite (1 in Fig. 9) has a trapezoidal shape and carries 2 short spines on the posterior lateral corner (2 in Fig. 9), which are the rudiments of the third pair of swimming legs found in later stages. The fourth somite (3 in Fig. 9) has a trapezoidal shape and represents the pre-genital and genital segments found in later stages. The fifth somite (4 in Fig. 9) has a long rectangular shape and bears 2 large caudal rami at its terminal tip (5 in Fig. 9). Each caudal ramus carries 3 plumose setae, 1 long (6 in Fig. 9) and 2 short (7 in Fig. 9), and 2 short setules (8 in Fig. 9). As in the adult, the males have longer, more robust caudal rami (Fig. 9a,b), whereas those of the female are smaller and finer (Fig. 9c,d). No other indications of sexual differentiation were found in the copepodid.

\section{DISCUSSION}

In many aspects, the free-swimming juvenile stages of Lernaeocera branchialis are very similar to those reported for other siphonostomatoids. In the pennellid Lernaeenicus sprattae (Sowerby, 1806), which parasitises sprat Sprattus sprattus (L.), only the number and positioning of the spines on the antennules anatomically distinguishes the nauplii from those of Lernaeocera branchialis. In Lernaeenicus sprattae, the antennule of the nauplius II bears 4 spines at its apical tip and 2 mid-way along the appendage 

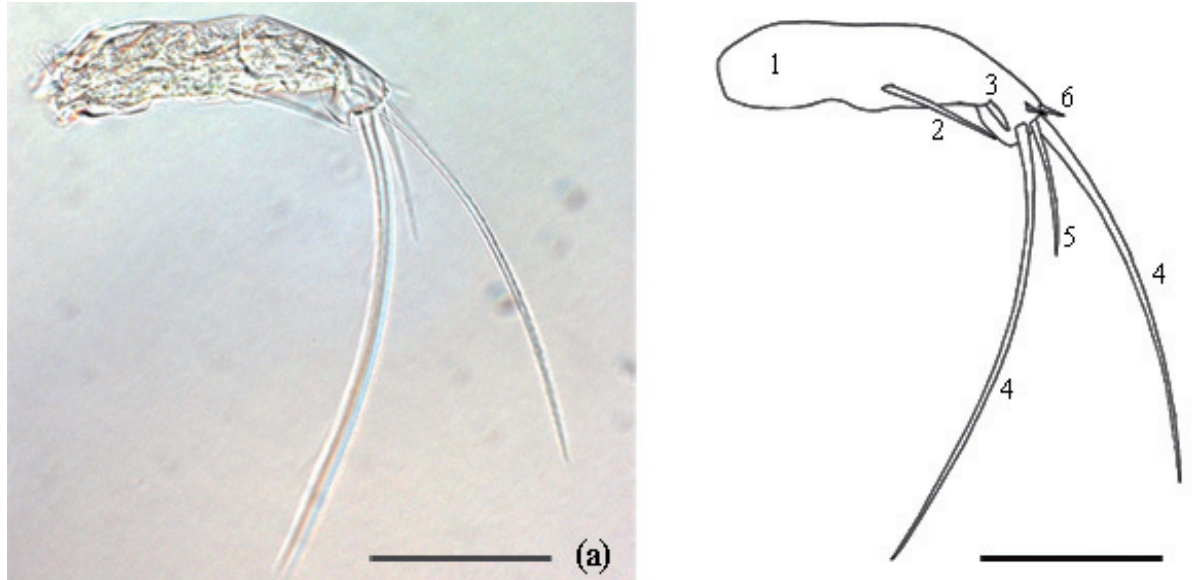

(b)
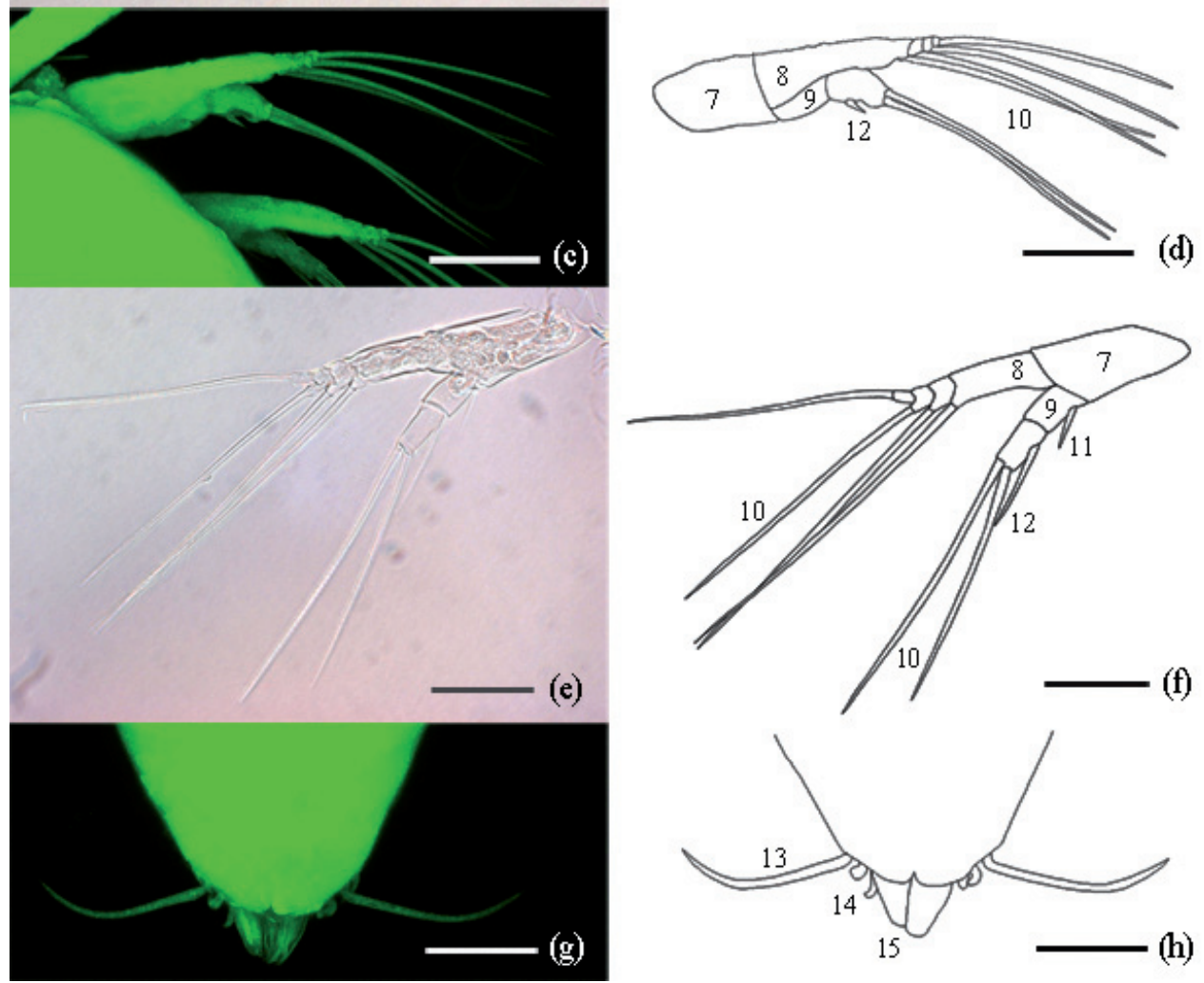

Fig. 4. Lernaeocera branchialis (L., 1767). Nauplius II. (a) Antennule, light micrograph (phase contrast), (b) antennule, line drawing, (c) antenna, confocal composite image, (d) antenna, line drawing, (e) mandible, light micrograph (phase contrast), (f) mandible, line drawing, (g) posterior, confocal composite image, (h) posterior, line drawing. Scale bars: $50 \mu \mathrm{m}$. Labels: 1 , endopod; 2, distal median setule (unarmed); 3, proximal median setule (unarmed); 4, plumose setae (hairs omitted); 5, terminal setule (unarmed); 6, sub-terminal spines; 7, sympod; 8, exopodite; 9, endopodite; 10, plumose setae (hairs omitted); 11, proximal setule (unarmed), 12, distal setule (unarmed); 13, balancers; 14, protrusions; 15, developing caudal rami

(Schram 1979), whereas in Lernaeocera branchialis, only 3 spines are found at the tip, plus 1 sub-terminal spine and 1 mid-way along the appendage. The segmentation and armature of the antennae and mandibles are identical for Lernaeenicus sprattae and Lernaeocera branchialis. Differences in colouration are present, with Lernaeenicus sprattae having a bluish-black pigment (Schram 1979) and Lernaeocera branchialis a red-black pigment.

The nauplii of the caligids Caligus elongatus von Nordmann, 1832 and Lepeophtheirus salmonis (Krøyer, 1837) are also very similar to those of Lernaeocera branchialis, although the overall body shapes are different with the caligids being more 


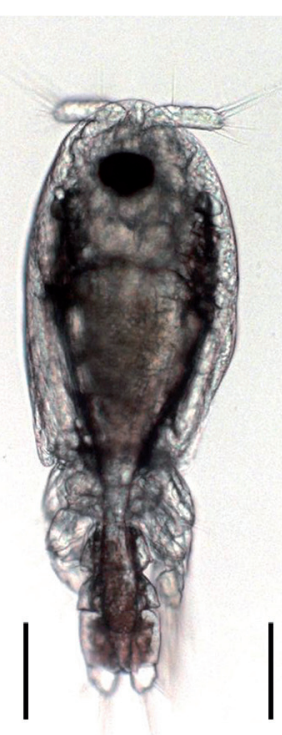

(a)
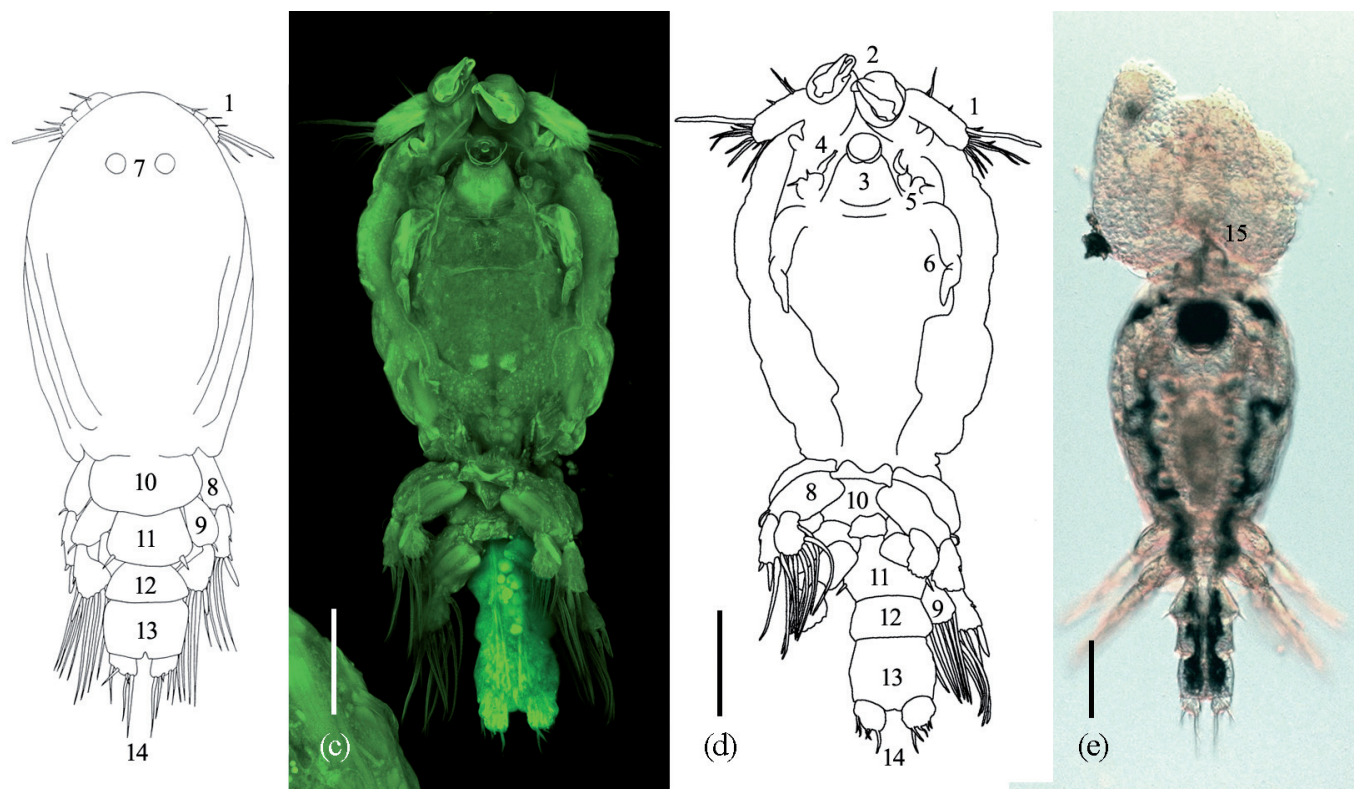

Fig. 5. Lernaeocera branchialis (L., 1767). Copepodid. (a) Light micrograph (dorsal aspect), (b) line drawing (dorsal aspect), (c) confocal composite image (ventral aspect), (d) line drawing (ventral aspect) (right swimming leg 1 and left swimming leg 2 are drawn without setae for clarity), (e) light micrograph (phase contrast) showing copepodid attached to a gill tip by its frontal filament. Scale bars: $100 \mu \mathrm{m}$. Labels: 1, antennule; 2, antenna; 3, buccal tube; 4, mandible; 5, maxillule; 6, maxilla; 7, eye lenses; 8, first swimming leg; 9, second swimming leg; 10, second thoracic somite; 11, third thoracic somite; 12, fourth thoracic somite; 13, fifth thoracic somite; 14, caudal rami; 15, frontal filament

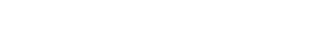



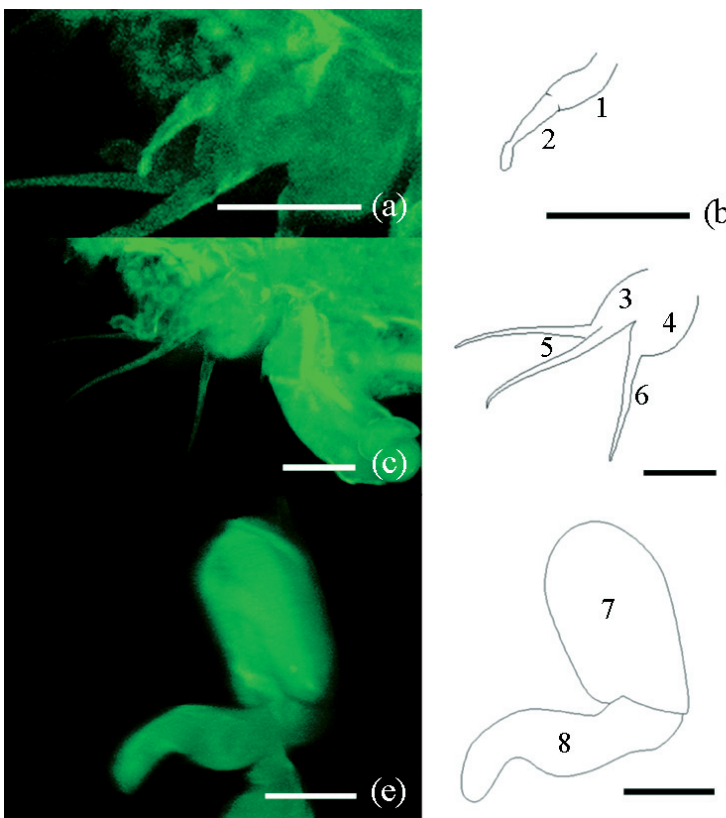

Fig. 7. Lernaeocera branchialis (L. 1767). Copepodid. (a) Mandible, confocal composite image, (b) mandible, line drawing, (c) maxillule, confocal composite image, (d) maxillule, line drawing, (e) maxilla, confocal composite image, (f) maxilla, line drawing. Scale bars: $25 \mu \mathrm{m}$. Labels: 1, proximal section; 2, distal section; 3, inner lobe; 4, outer lobe; 5, setiform processes; 6 , setiform process; 7, basal ramus; 8 , terminal ramus elongate (Johnson \& Albright 1991, Piasecki 1996). The main distinction between the appendages of $C$. elongatus, Lepeophtheirus salmonis and Lernaeocera branchialis is the segmentation of the antennules in the caligids, whereas in Lernaeocera branchialis the antennule is unsegmented.

The armature of the nauplius II terminal tip differs from other described pennellids, in that part of the developing caudal rami is visible extending from the terminus of the nauplius and 2 small protrusions are present on each side of the caudal rami, representing the setae of the caudal rami in later stages. In Lepeophtheirus salmonis the balancers of the nauplius II are in a position homologous to the fourth setae of the caudal rami (Huys et al. 2007). As the balancers of the Lernaeocera branchialis nauplius II appear to occupy the same position as those in Lepeophtheirus salmonis, it is likely that the balancers and small protrusions found in the nauplius II become the 3 innermost setae of the caudal rami in the copepodid.

The mean length of the copepodids of Lernaeocera branchialis was found to be greater than other pennellids, with the average length of $L$. branchialis being $628 \mu \mathrm{m}$ (present study, from confocal) compared to $450 \mu \mathrm{m}$ in Cardiodectes sp. (a pennellid parasitic on fish, which infects snails as its intermedi-
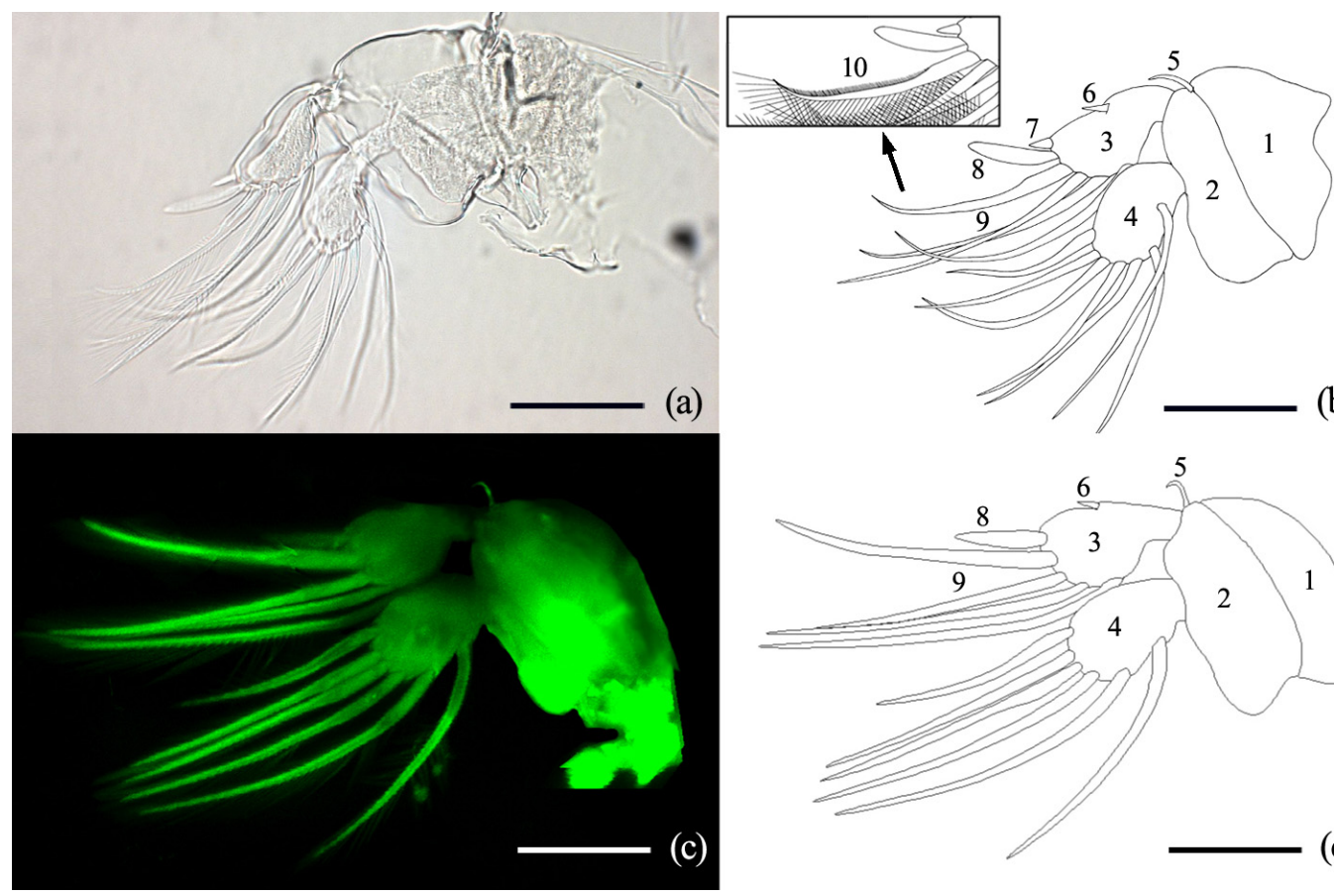

(b)

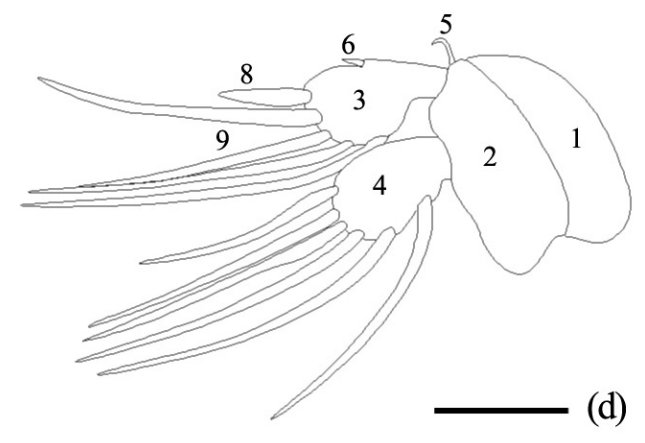

Fig. 8. Lernaeocera branchialis (L., 1767). Copepodid swimming legs. (a) First leg, light micrograph (phase contrast), (b) first leg, line drawing, (c) second leg, confocal composite image, (d) second leg, line drawing. Scale bars: $50 \mu \mathrm{m}$. Labels: 1, coxa; 2, basis; 3, exopodite; 4, endopodite; 5, plumose setule (hairs omitted); 6, spine; 7, blunt spine; 8, papilliform outgrowth; 9 , plumose setae (hairs omitted); 10, insert showing fringe of short hairs on the outermost seta 

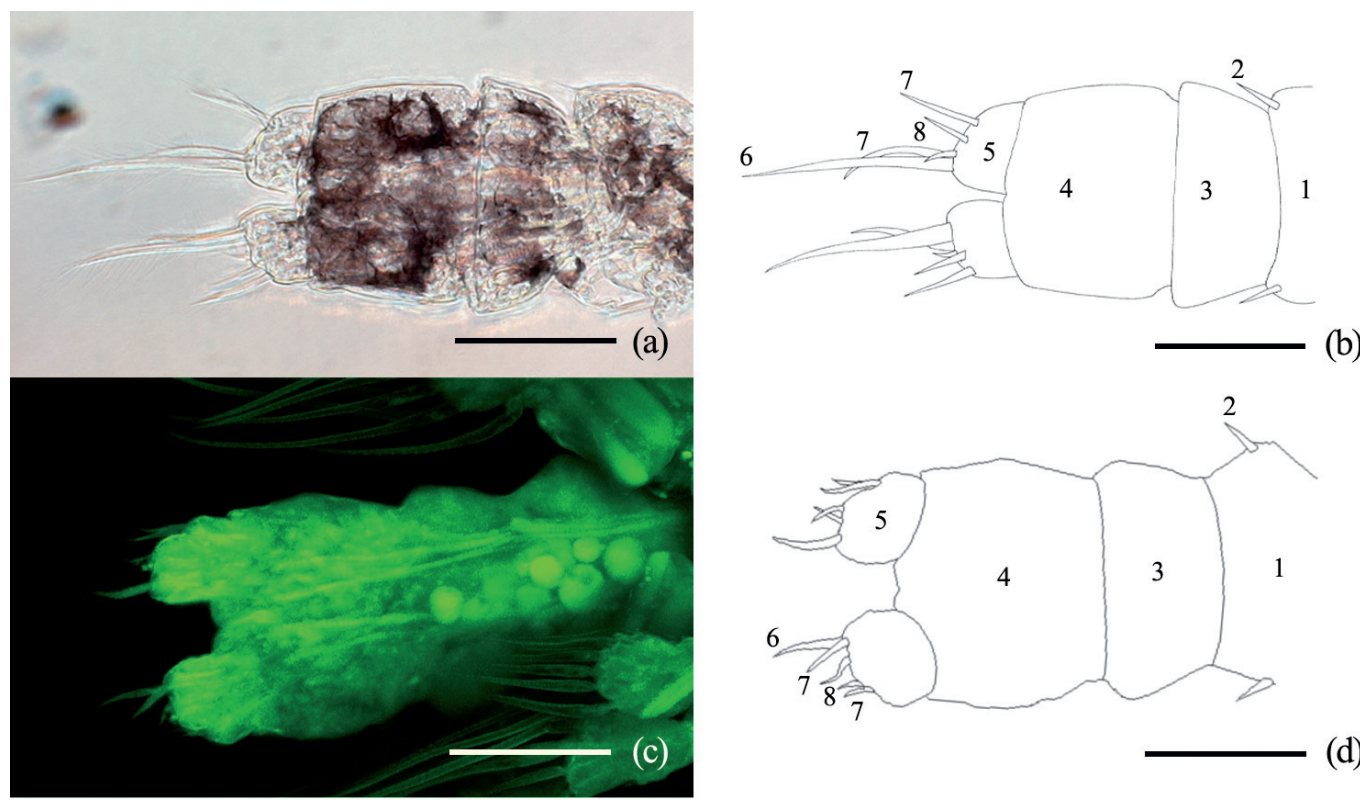

(b)

Fig. 9. Lernaeocera branchialis (L., 1767). Copepodid abdominal region. (a) Male dorsal aspect, light micrograph (phase contrast), (b) male dorsal aspect, line drawing, (c) female ventral aspect, confocal composite image, (d) female ventral aspect, line drawing. Scale bars: $50 \mu \mathrm{m}$. Labels: 1 , third thoracic somite; 2 , spine; 3, fourth thoracic somite; 4, fifth thoracic somite; 5 , caudal ramus; 6 , long plumose seta; 7 , short plumose seta; 8 , setule

ate host) (Ho 1966) and $480 \mu \mathrm{m}$ in Penella varians Steenstrup et Lütken, 1861 (a pennellid parasitic on cephalopods) (Rose \& Hamon 1953). Only copepodids of Lernaeenicus sprattae have a mean length greater than $628 \mu \mathrm{m}$ (Schram 1979). The pigmentation varies between different pennellids: Lernaeocera branchialis displays red and black pigmentation; Lernaeenicus sprattae shows a bluish-black pigmentation (Schram 1979), and Cardiodectes sp. is covered in dark blotches (Ho 1966).

The armature of the antennule in Lernaeocera branchialis is similar to those of Lernaeenicus sprattae, Cardiodectes sp., and Penella varians, except for the fact that the terminal segment of $L$. sprattae has 1 less seta (12) (Schram 1979), Cardiodectes has 2 fewer setae (11) (Ho 1966) and $P$. varians has 3 fewer setae (10) (Rose \& Hamon 1953), compared to 13 setae in L. branchialis. The antenna of Lernaeocera branchialis appears to differ from that of other pennellids that have been described, in that it has a blunt process on the distal border of the terminal segment instead of a spine (Jungersen 1913, Rose \& Hamon, 1953, Schram 1979). In pennellids, the antenna consists of 2 segments, whereas in caligids the endopod is fused to form a single segment (Boxshall 1990).

The relative proportions of the labrum and labium that form the buccal tube in copepodids of Lernaeocera branchialis differ from those of Cardiodectes sp. In $L$. branchialis both the labrum and labium con- tribute an equal portion of the buccal tube, whereas in Cardiodectes sp., the labrum is smaller and only the labium is connected with the marginal membrane (Ho 1966), which is a feature found in later stages of L. branchialis.

The segmentation and armature of the copepodid mandible and maxillule are identical for Lernaeocera branchialis and most other pennellids that have been described, the mandible consisting of a single segment with a sharp pointed terminal tip, which represents the coxal gnathobase, and the maxillule being bilobed, both of which are features homologous to those of caligids (Boxshall 1990). Only the maxillule of Cardiodectes sp. differs, having a small exopod bearing a single seta, which appears to be absent in other pennellids. Similarly, the maxilla of pennellids and caligids are homologous, consisting of 2 segments representing the coxa and a long attenuated basis. Ho (1966) described the maxilla of Cardiodectes sp. as having 3 segments. However, this may have been a misidentification, resulting in the hooked tip of the terminal segment being described as a separate third segment.

The segmentation and armature of the swimming legs of Lernaeocera branchialis copepodids appear to be identical to other pennellids that have been described (Rose \& Hamon 1952, Ho 1966, Schram 1979). As in other siphonostomatoids, the first thoracic somite is fully fused with the cephalothorax 
(Huys \& Boxshall 1991). The fusion of the pre-genital and genital segments to form a genital complex is homologous with caligids and possibly other siphonostomatoids parasitic on fish (Boxshall 1990). The thoracic segments of Lernaeenicus sprattae, Cardiodectes sp. and Lernaeocera branchialis are identical although the caudal rami differ (Ho 1966, Schram 1979). In L. branchialis, each caudal ramus bears 3 plumose setae and 2 setules, whereas in Cardiodectes sp. and Lernaeenicus sprattae, each caudal ramus bears 4 plumose setae and 1 setule (Ho 1966, Schram 1979). In addition, the medial border of the caudal ramus in Cardiodectes sp. bears a row of fine setae (Ho 1966), but these are absent in Lernaeenicus sprattae and Lernaeocera branchialis.

In all other pennellids that have been described, copepodids have been observed both free-swimming and attached to the host by a frontal filament. In Lernaeocera branchialis, it was previously thought that the frontal filament is extruded during the moult to chalimus I (Sproston 1942). The current observations and those of other workers, however, suggest that the frontal filament in pennellids is extruded before the moult to chalimus I (Rose \& Hamon 1952, 1953, Ho 1966, Schram 1979). This has been confirmed in Cardiodectes sp., where several copepodids attached by their frontal filament were observed moulting to chalimus I and their exuviae were exact templates of the free-swimming copepodid (Ho 1966). It is likely that the extrusion of the frontal filament and attachment to the host are the first events in the sequence culminating in the moult to chalimus I. The frontal filament of pennellids appears to differ from that of caligids in that it is bifurcate (Ho 1966, Schram 1979), whereas in caligids the filament consists of a single strand (Piasecki \& MacKinnon 1993, Pike et al. 1993, Gonzalez-Alanis et al. 2001). Further study of $L$. branchialis is required to confirm the timing of the frontal filament production, and describe its development and ultrastructure.

\section{CONCLUSIONS}

The last detailed description of the juvenile stages of Lernaeocera branchialis was provided by Sproston (1942). In the present study, the free-swimming juvenile stages have been successfully re-described, including the nauplius II stage, which was not found by Sproston (1942). As part of the nauplius II description, 4 small protrusions, representing the setae of the caudal rami found in later stages, and the developing caudal rami were found at the terminal tip.
These structures were not found in the nauplius II stages of other pennellids that have been described.

The use of a combination of light microscopy and LSCM demonstrates the differences between these 2 techniques for morphological taxonomy and highlights the advantages of LSCM over traditional methods - primarily the ability to image whole specimens in detail without the need to dissect individual appendages. A more detailed discussion of morphological taxonomy using LSCM can be found in Brooker et al. (2012).

Lernaeocera branchialis is recognised as a pathogen that could have major effects on the aquaculture industry (Khan et al. 1990, Bricknell et al. 2006). With renewed interest in $L$. branchialis as a result of the expansion of gadoid aquaculture in several North Atlantic countries, this re-description provides important information on its life history, which may form the basis of further research into this potentially devastating pathogen.

Acknowledgements. This project was funded by a NERC studentship awarded to A.J.B.

\section{LITERATURE CITED}

Boxshall GA (1990) The skeletomusculature of siphonostomatoid copepods, with an analysis of adaptive radiation in structure of the oral cone. Philos Trans R Soc Lond, B 328:167-212

Boxshall GA (1992) Copepoda. In: Harrison FW, Humes AG (eds) Microscopic anatomy of invertebrates, Vol 9: Crustacea. Wiley-Liss, New York, p 347-384

Bricknell IR, Bron JE, Bowden TJ (2006) Diseases of gadoid fish in cultivation: a review. ICES J Mar Sci 63:253-266

Brooker AJ, Shinn AP, Bron JE (2007) A review of the biology of the parasitic copepod Lernaeocera branchialis (L. 1767) (Copepoda: Pennellidae). Adv Parasitol 65: 297-341

Brooker AJ, Shinn AP, Bron JE (2012) Use of laser scanning confocal microscopy for morphological taxonomy and the potential for digital type specimens (e-types). Aquat Biol 14:165-173

Capart A (1948) Lernaeocera branchialis. Cellulae 52: $159-212$

- Gomori G (1950) A rapid one-step trichrome stain. Am J Clin Pathol 20:661-664

Gonzalez-Alanis P, Wright GM, Johnson SC, Burka JF (2001) Frontal filament morphogenesis in the salmon louse Lepeophtheirus salmonis. J Parasitol 87:561-574

Ho JS (1966) Larval stages of Cardiodectes sp. (Caligoida: Lernaeoceriformes), a copepod parasitic on fishes. Bull Mar Sci 16:159-199

Huys R, Boxshall GA (1991) Copepod evolution. Ray Society, London

Huys R, Llewellyn-Hughes J, Conroy-Dalton S, Olson PD, Spinks JN, Johnston DA (2007) Extraordinary host switching in siphonostomatoid copepods and the demise of the Monstrilloida: integrating molecular data, onto- 
geny and antennulary morphology. Mol Phylogenet Evol 43:368-378

Johnson SC, Albright LJ (1991) The developmental stages of Lepeophtheirus salmonis (Krøyer, 1837) (Copepoda: Caligidae). Can J Zool 69:929-950

Jungersen HFE (1913) On a new gymnoblastic hydroid (Ichthyocodium sarcotretis) epizoic on a new parasitic copepod (Sarcotretes scopeli) infesting Scopelus glacialis Rhdt. Vidensk Medd Dan Nathist Foren 64:1-33

Kabata Z (1957) Lernaeocera obtusa n. sp. a hitherto undescribed parasite of the haddock (Gadus aeglefinus). J Mar Biol Assoc U K 36:569-592

Kabata Z (1958) Lernaeocera obtusa. n. sp. its biology and its effects on the haddock. Mar Res 3:1-26

Kabata Z (1961) Lernaeocera branchialis (L.), a parasitic copepod from the European and American shores of the Atlantic. Crustac 2:243-249

Kabata Z (1962) The mouth and mouthparts of Lernaeocera branchialis L. Crustac 3:311-317

Kabata Z (1979) Parasitic Copepoda of British fishes. Ray Society, London

Khan RA, Lee EM, Barker D (1990) Lernaeocera branchialis: A potential pathogen to cod ranching. J Parasitol 76: 913-917

Piasecki W (1996) The developmental stages of Caligus elongatus von Nordmann, 1832 (Copepoda: Caligidae). Can J Zool 74:1459-1478

Piasecki W, MacKinnon BM (1993) Changes in structure of the frontal filament in sequential developmental stages of Caligus elongatus von Nordmann, 1832 (Crustacea,

Editorial responsibility: Söhnke Johnsen, Durham, North Carolina, USA
Siphonostomatoida). Can J Zool 71:889-895

Pike AW, MacKenzie K, Rowand A (1993) Ultrastructure of the frontal filament in chalimus larvae of Caligus elongatus and Lepeophtheirus salmonis from Atlantic salmon, Salmo salar. In: Boxshall GA, Defaye D (eds) Pathogens of wild and farmed fish: sea lice. Ellis Horwood, Chichester, p 99-113

Rose M, Hamon M (1952) Sur un copépode parasite de certains mollusques ptéropodes théeosomes. Ann Nat Zool 14:219-230

Rose M, Hamon M (1953) Apropos de Penella varians Steenstrup \& Lütken, 1861, parasite des branchies de céphalopodes. Bulle Soc Hist Nat Afr Nord 44:172-183

Schram TA (1979) The life history of the eye-maggot of the sprat, Lernaeenicus sprattae (Sowerby) (Copepoda, Lernaeoceridae). Sarsia 64:279-316

> Schuurmans-Stekhoven JHJ (1936) Beobachtungen zur Morphologie und Physiologie der Lernaeocera branchialis L. und der Lernaeocera lusci Bassett-Smith (Crustacea parasitica). Z Parasitenkd 8:659-698

Scott A (1901) Lepeophtheirus and Lernaea. Liverpool Mar Biol Comm Mem 6:1-54

Sproston NG (1942) The developmental stages of Lernaeocera branchialis. J Mar Biol Assoc U K 25:441-446

Van Damme PA, Ollevier F (1995) Morphological and morphometric study of crustacean parasites within the genus Lernaeocera. Int J Parasitol 25:1401-1411

Wilson CB (1917) North American parasitic copepods belonging to Lernaeidae, with a revision of the entire family. Proc US Natl Mus 53:1-150

Submitted: March 11, 2011; Accepted: October 25, 2011

Proofs received from author(s): December 31, 2011 